Jurnal IImiah Iqra'

2541-2108 [Online] 1693-5705 [Print]

Tersedia online di: http://journal.iain-manado.ac.id/index.php/JII

\title{
Implementasi Kinerja Komite Sekolah di Madrasah Tsanawiyah Kecamatan Oba Utara Kota Tidore Kepulauan
}

\author{
Julkarnain Syawal \\ IAIN Ternate, Ternate, Indonesia \\ julkarnainsyawal@iain-ternate.ac.id
}

\section{Mubin Noho}

IAIN Ternate, Ternate, Indonesia

mubinnoho@iain-ternate.ac.id

\begin{abstract}
Abstrak
Penelitian ini menjawab dua masalah yakni bagaimana pelaksanaan kinerja Komite Sekolah MTs di Kecamatan Oba Utara? Bagaimana kendala yang dihadapi Komite Sekolah MTs di Kecamatan Oba Utara dalam pelaksanaan kinerjanya? Metode penelitian yang digunakan adalah kualitatif, data penelitian bersumber dari kepustakaan (bahan cetak) dan human resources yang diperoleh melalui observasi, wawancara, dan dokumentasi. Data tersebut kemudian dianalisis menggunakan teknik analisis deskriptif kualitatif. Hasil penelitian menunjukan bahwa Kinerja komite madrasah Tsanawiyah di Kecamatan Oba Utara belaum berjalan secara maksimal. Implementasi kinerja komite MTs di kecamatan Oba Utara umunya masih berada pada fungsi supporting agency, itu pun masih terbatas pada supporting dana serta sarana prasarana pendidikan. Kendala yang di hadapi oleh komite madrasah Tsanawiyah di kecamatan Oba Utara adalah minimnya sumberdaya manusia. Pengurus yang dipercayakan untuk mejadi komite sekolah ini pada umumnya belum memahami sesungguhnya peran dan fungsi komite sebagaimana tertuang dalam peraturan yang ditetapkan. Kepedulian pemerintah terhadap komite sekolah juga merupakan faktor yang menyebabkan minimnya sumber daya manusia pada pengurus komite sekolah. Faktor kedua yang menjadi kendala adalah ketersediaan waktu dan kesempatan pengurus komite dalam menjalankan tugas dan fungsi komite madrasah.
\end{abstract}

Kata Kunci: Komite Sekolah; Kinerja

\section{Abstract}

This research, to answer two problems that was; How to apply the performance of school committee at MTs of Sub-district north Oba? How to obstacles to face school committee at MTs of Sub-district north Oba to applying the performance? The research was using Qualitative method and the data sourced to library, human resources, observation, interview and documentations. The data analysis was using descriptive 
qualitative. The result was finding of committee performance at MTs of sub - district north Oba raining well yet. Implementation of committee performance at MTs Subdistrict north Oba generally the function still was supporting agency, It limited on supporting agency and educational infrastructure. The constraining to face by committee at MTs of Sub-districts north Oba that was: the minimum of human resource. The administrator who has entrusted to become school committee not yet understanding and the role of committee function as discussed on the poured of regulation that assign. Government concern on school committee was factoring to the constrain of the minimum of human resource on the administrator school committee Second, the causative effect availability on time and chance committee board to run as duty and function committee at Mts.

Keywords: Committee of school; Performance.

\section{Pendahuluan}

Pemberlakuan desentralisasi pendidikan di Indonesia pada prisnsipnya memberikan kewenangan kepada daerah untuk mengelola pendidikan yang bertumpu pada landasan demokratisasi. Sebagaimana penjelasan H.A.R. Tilaar yang menyatakan bahwa hal tersebut pada intinya adalah "memberikan kesempatan kepada rakyat untuk mengambil keputusan di lapangan mengenai bentuk, proses dan keberadaan lembaga pendidikan yang sesuai dengan tuntutan kehidupannya" (Tilaar, 2009). Pernyataan tersebut memberikan satu ketegasan bahwa masyarakat tidak lagi diposisikan sebagai objek dari kebijakan pendidikan, namun masyarakat memiliki peran yang penting dalam perumusan pengelolaan pendidikan. Dengan demikian, Keterlibatan stake holder dalam pengelolaan pendidikan merupakan satu keharusan dalam desentralisasi pendidikan.

Pemberlakuan desentralisasi pendidikan berdasarkan Undang-undang nomor 22 tahun 1999 Jo. UU Nomor 32 Tahun 2004 yang mengatur tentang pemerintahan daerah. Salah satu urusan wajib yang menjadi kewenangan pemerintah daerah berskala kabupaten kota adalah penyelenggaraan pendidikan. Dari rahim undangundang ini kemudian lahirlah berbagai regulasi yang mengatur secara khusus pengelolaan pendidikan di daerah. Salah satu regulasi tersebut adalah regulasi yang mengatur tentang komite sekolah (School Commite). Undang-undang tersebut jika 
diimbangi dengan desain kurikulum didesain kurikulum secara sistematis dan komprehensif serta integral dengan segala kebutuhan pengembangan dan pembelajaran peserta didik, tentu hasil atau output pendidikan dapat mewujudkan harapan bersama (Daeng Pawero, 2018).

Kehadiran komite sekolah merupakan aplikasi dari konsep pengelolaan pendidikan yang demokratis di era otonomi daerah. Eksistensinya diperkuat dengan undang-undang nomor 25 tahun 2000 tentang Program Pembangunan Nasional (Propenas) tahun 2000-2004 pada program pembangunan pendidikan dasar dan menengah yang mendorong terwujudnya school communit based management dengan membentuk komite sekolah (pendidikan) di setiap kabupaten kota. Program ini selanjutnya dijabarkan dalam keputusan menteri pendidikan nasional Nomor 044/U/2002 Tentang Komite Sekolah, dan Undang-undang nomor 20 tahun 2003 tentang sistem pendidikan nasional. Dari regulasi inilah yang kemudian menjadi payung hukum bagi terbentuknya Komite Sekolah.

Komite sekolah merupakan lembaga yang dibentuk atas prakarsa dari stake holder di setiap satuan pendidikan sebagai manifestasi keikutsertaan masyarakat dalam mengelola pendidikan. Dalam keputusan menteri pendidikan nasional nomor 044/U/2002 menjelaskan bahwa Komite Sekolah adalah badan mandiri yang mewadahi peranserta masyarakat dalam rangka meningkatkan mutu, pemerataan, dan efisiensi pengelolaan pendidikan di satuan pendidikan, baik pada pendidikan pra sekolah, jalur pendidikan sekolah maupun jalur pendidikan luar sekolah. Pada pasal 192 PP nomor 17 tahun 2010 juga dijelasskan bahwa “Komite sekolah/madrasah berfungsi dalam peningkatan mutu pelayanan pendidikan dengan memberikan pertimbangan, arahan dan dukungan tenaga, sarana dan prasarana, serta pengawasan pendidikan pada tingkat satuan pendidikan. Jika demikian, maka kehadiran komite sekolah sangat membantu peningkatan mutu pendidikan di Indonesia. 
Keberadaan komite sekolah pada setiap satuan pendidikan merupakan "angin segar" bagi dunia pendidikan. Dikatakan demikian karena ada ruang yang diberikan bagi para stake holder untuk berperan serta dalam pengelolaan pendidikan, sehingga pemerintah tidak lagi menjadi satu-satunya sumber pengelolaan pendidikan (Pawero, 2017). Akan tetapi, angin segar tersebut tidak bertiup merata pada semua satuan pendidikan yang sesungguhnya membutuhkan hal tersebut. Hal ini berarti bahwa masih ada komite sekolah yang belum menjalankan tugas dan fungsinya secara baik.

Kota Tidore khususnya kecamatan Oba Utara tidak terlepas dari berbagai persoalan pendidikan sebagaimana daerah lain di Indonesia. Harapan desentralisasi pendidikan yang menitik beratkan pada partisipasi stake holder dalam perumusan kebijakan dan pengelolaan pendidikan belum sepenuhnya sesuai dengan tuntutan perundang-undangan. Komite sekolah sebagai wadah penyaluran aspirasi masyarakat, dan pengontrol penyelenggaraan pendidikan pada satuan tidak dapat berbuat banyak dalam menjalankan tugas dan fungsinya.

Dari gambaran tersebut di atas menunjukan bahwa masih terdapat sejumlah persoalan komite sekolah untuk menjalankan tugas dan fungsinya dalam penyelenggaraan pendidikan di setiap satuan pendidikan. Oleh karena itu, merupakan satu hal yang sangat penting untuk melakukan riset terhadap penerapan kinerja komite sakolah. Riset ini bertujuan untuk mengeksplorasi kinerja komite madrasah Tsanawiyah di Kecamatan Oba Utara, serta kendala yang dihadapi oleh komite madrasah dalam menjalankan tugas dan fungsinya.

\section{Kajian Teori}

\section{Manajemen Berbasis Sekolah}

Manajemen berbasis sekolah marupakan pelimpahan kewenangan dari pemerintah kepada sekolah. Caldwell dalam Felipe Barrera, menyebutkan bahwa 
School-based management is the decentralization of authority from the central government to the school level (Barrera \& et.all, 2009). Pernyataan tersebut memberikan gambaran bahwa manajemen berbasis sekolah memposisikan sekolah sebagai sasaran pelimpahan wewenang dari pemerintah pusat. Wewenang yang dimaksudkan adalah wewenang dalam tata kelola pendidikan.

Umiarso mengemukakan bahwa manajemen berbasis sekolah pada intinya adalah memberikan kewenangan terhadap sekolah untuk melakukan pengelolaan dan perbaikan kualitas secara terus menerus (Umiraso \& Gojali, 2011). Berangkat dari pengertian di atas, dapat ditarik satu pemikiran bahwa manajemen berbasis sekolah adalah pelimpahan kewenangan oleh pemerintah kepada sekolah untuk melakukan pengelolaan sekolah secara mandiri dalam rangka perbaikan kualitas pendidikan.

Pelaksanaan manajemen berbasis sekolah mensyaratkan agar sekolah dan pemangku kepentingan dapat mengubah perilaku dan praktek mereka termasuk cara melibatkan diri dalam kegiatan yang tak pernah mereka lakukan sebelumnya seperti merencanakan dan mengembangkan kurikulum atau program akademis (World Bank, 2013).

Menurut Hasbullah, dalam pelaksanaan MBS memilki beberapa faktor yang perlu diparhatikan diantaranya:

1. Sekolah dituntut untuk mampu menampilkan pengelolaan sumber daya secara transparan, demokratis, tanpa monopoli, dan tanggung jawab terhadap masyarakat maupun pemerintah.

2. Peranan pemerintah merumuskan kebijakan pendidikan yang menjadi prioritas nasional dan merumuskan MBS. Sekolah menjabarakannya sesuai dengan potensi sekolah.

3. Perlu bentuk schoool council (dewan sekolah/komite sekolah) yang keanggotaannya terdiri dari guru, kepala sekolah, orang tua peserta didik, dan masyarakat.

4. MBS menuntut perubahan perilaku kepala sekolah, guru, dan tenaga adminsitrasi menjadi lebih profesional dan manajerial dalam pengoperasian sekolah. 
5. Dalam meningkatkan profesionalisme dan kemampuan manajemen yang terkait dengan MBS perlu diadakan kegiatan-kegiatan seperti pelatihan dan sejenisnya.

6. Keefektifan MBS dapat dilihat dari indikator-indikator sejauh mana sekolah dapat mengoptimalkan kinerja organisasi sekolah, proses pembelajaran, pengelolaan sumber daya manusia dan administrasi (Hasbullah, 2010).

\section{Komite Sekolah}

Secara umum, komite sekolah dapat dimaknai sebagai sebuah badan lembaga mandiri non profit serta non politis yang dibentuk oleh tokoh masyarakat yang mempunyai kepedulian terhadap pendidikan dan warga sekolah secara demokratis. Dalam peraturan pemerintah nomor 17 tahun 2010 dijelaskan bahwa "komite sekolah/madrasah adalah lembaga mandiri yang beranggotakan orang tua/wali peserta didik, komunitas sekolah, serta tokoh masyarakat yang peduli pendidikan". Dalam pasal 56 Undang-undang Nomor 20 tahun 2003 tentang sisdiknas menjelaskan bahwa:

1. Masyarakat berperan dalam peningkatan mutu pelayanan pendidikan yang meliputi perencanaan, pengawasan, dan evaluasi program pendidikan melalui dewan pendidikan dan komite sekolah/madrasah.

2. Komite sekolah/madrasah, sebagai lembaga mandiri, dibentuk dan berperan dalam peningkatan mutu pelayanan dengan memberikan pertimbangan, arahan dan dukungan tenaga, sarana dan prasarana, serta pengawasan pendidikan pada tingkat satuan pendidikan (Tim Redaksi Sinar Grafika, 2007).

Secara umum dijelaskan bahwa terdapat beberapa hal yang menjadi tujuan pembentukan komite sekolah adalah:

1. Sebagai wadah penyaluran aspirasi dan insiatif masyarakat dalam melahirkan kebijakan dan program pendidikan di satuan pendidikan.

2. Meningkatkan tanggung jawab dan peran serta aktif dari seluruh lapisan masyarakat dalam penyelenggaraan pendidikan.

3. Menciptakan suasana dan kondisi transparan, akuntabel, dan demokratis dalam penyelenggaraan dan pelayanan pendidikan yang bermutu di satuan pendidikan

Bjork dalam BEC-TF mengemukakan penjelasannya bahwa jika situasinya memungkinkan dan mendukung komite sekolah, banyak hasil positif yang dicapai diantranya : 
1. Kebanyakan orang tua mengetahui tentang komite, nama pimpinan, serta anggota-anggotanya;

2. Komite mengadakan pertemuan dengan anggotanya lebih sering dibandingkan dengan $\mathrm{BP}_{3}$ dahulu, dan juga bertemu orang tua siswa dan guru lebih rutin, berfungsi sebagai saluran multi dimensi diantara masyarakat dan sekolah; dimana orang tua bisa berbagi ide dan mengajukan pertanyaan;

3. Dalam kondisi terbaik, komite mempunyai akses ke personil sekolah dan memberikan masukan pada perencanaan sekolah, penentuan anggaran, dan pembuatan keputusan dan bisa membantu penggalangan dana untuk peningkatan kualitas sekolah lebih lanjut (seperti misalnya mendukung program-program di luar kelas/ setelah jam sekolah, meningkatkan fasilitas sekolah, mempekerjakan pegawai tidak tetap);

4. Komite sekolah yang mempunyai status lebih tinggi di atas rata-rata (misalnya: karena mereka dipilih secara demokratis dan dipandang sebagai perwakilan dari masyarakat dan/ atau karena ketuanya berpengalaman dan terpelajar), juga mendorong tingkat kehadiran guru yang lebih tinggi dan guru memiliki lebih banyak waktu untuk berbagai kegiatan seperti persiapan pembelajaran dan evaluasi siswa (Basic Education Capacity Trust Fund (BEC-TF), 2011).

\section{Peran dan Fungsi Komite Sekolah}

Untuk mencapai tujuan tersebut, dijabarkan peran dan fungsi yang harus dijalankan oleh dewan pendidikan yaitu sebagai pemberi pertimbangan (advisory agency), pemberi dukungan (supporting agency, pengontrol (controlling agency), dan mediator. Peranan tersebut merupakan satu kesatuan yang mesti dijalankan sebagai manifestasi dari peranan stake holder dalam ikut serta meningkatkan pelayanan dan mutu pendidikan (Pawero, 2017).

Dalam Kepmendiknas No. 44/U/ 2002 juga dijelaskan fungsi komite sekolah dalam menjalankan tugasnya yaitu:

1. Mendorong tumbuhnya perhatian dan komitmen masyarakat terhadap penyelenggaraan pendidikan yang bermutu; 
2. Melakukan kerjasama dengan masyarakat (perorangan/organisasi/dunia usaha/dunia industri) dan pemerintah berkenaan dengan penyelenggaraan pendidikan yang bermutu;

3. Menampung dan menganalisis aspirasi, ide, tuntutan, dan berbagai kebutuhan pendidikan yang diajukan oleh masyarakat;

4. Memberikan masukan, pertimbangan, dan rekomendasi kepada satuan pendidikan mengenai:

a. kebijakan dan program pendidikan;

b. Rencana Anggaran Pendidikan dan Belanja Sekolah (RAPBS);

c. kriteria kinerja satuan pendidikan;

d. kriteria tenaga kependidikan;

e. kriteria fasilitas pendidikan; dan

f. hal-hal lain yang terkait dengan pendidikan;

5. Mendorong orangtua dan masyarakat berpartisipasi dalam pendidikan guna mendukung peningkatan mutu dan pemerataan pendidikan;

6. Menggalang dana masyarakat dalam rangka pembiayaan penyelenggaraan pendidikan disatuan pendidikan;

7. Melakukan evaluasi dan pengawasan terhadap kebijakan, program, penyelenggaraan, dan keluaran pendidikan di satuan pendidikan.

Peran dan fungsi komite sekolah tersebut di atas kemudian dijabarkan beberapa indikator peran komite sekolah oleh Ace Suryadi dan Dasim Budimansyah sebagaimana dikutip Hasbullah sebagai berikut (Hasbullah, 2010).

Tabel.1 Indikator Peran Komite Sekolah

\begin{tabular}{|c|c|c|c|}
\hline Peran Komite & & Fungsi & Indikator Kinerja \\
\hline Sekolah & & Manajemen & \\
\hline \multirow[t]{3}{*}{ Advisory agency } & 1. & Perencanaan sekolah & $\begin{array}{ll}\text { - } & \text { Identifikasi sumberdaya pendidikan } \\
\text { - } & \text { dalam masyarakat; } \\
\text { - } & \text { Menberikan masukan RAPBS } \\
\text { - } & \text { Memberikan pertimbangan } \\
\text { - } & \text { perubahan RAPBS } \\
& \text { Ikut mengesahkan RAPBS bersama } \\
& \text { kepala sekolah } \\
\end{array}$ \\
\hline & 2. & $\begin{array}{l}\text { Pelaksanaan program } \\
\text { a. Kurikulum } \\
\text { b. PBM } \\
\text { c. Penilaian }\end{array}$ & 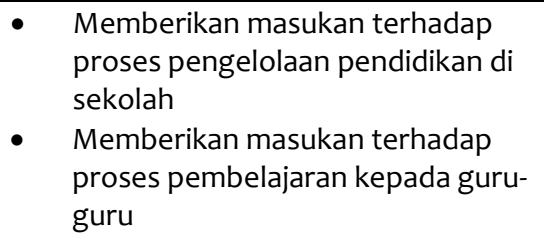 \\
\hline & & $\begin{array}{l}\text { Pengadaan } \\
\text { sumberdaya } \\
\text { pendidikan (SDM, S/P, }\end{array}$ & $\begin{array}{l}\text { - } \quad \text { Identifikasi sumber daya pendidikan } \\
\text { dalam masyarakat } \\
\text { - } \quad \text { Memberikan pertimbangan tentang } \\
\text { tenaga kependidikan yang dapat }\end{array}$ \\
\hline
\end{tabular}




\begin{tabular}{|c|c|c|}
\hline & Anggaran & $\begin{array}{l}\text { diperbantukan di sekolah } \\
\text { Memberikan pertimbangan tentang } \\
\text { sarana dan prasarana yang dapat } \\
\text { diadakan di sekolah } \\
\text { Memberikan pertimbangan } \\
\text { anggaran yang dapat dimanfaatkan } \\
\text { di sekolah }\end{array}$ \\
\hline \multirow[t]{3}{*}{ Suporting Agency } & 1.Sumber Daya & $\begin{array}{ll}\text { - } & \text { Pemantauan terhadap kondisi } \\
\text { ketenagaan pendidikan di sekolah } \\
\text { - } \\
\text { Mobilisasi guru sukarelawan di } \\
\text { sekolah } \\
\text { - } \quad \text { Mobilisasi tenaga kependidikan non } \\
\text { guru di sekolah } \\
\text { - Memantau kondisi sarana prasarana } \\
\text { di sekolah }\end{array}$ \\
\hline & 2. Sarana dan prasarana & $\begin{array}{ll}\text { - } & \text { Mobilisasi bantuan sarana/prasarana } \\
\text { di sekolah } \\
\text { - } \quad \text { Koordinasi dukungan sarana } \\
\text { - } \quad \text { Evasarana di sekolah } \\
\text { Evaluasi pelaksanaan dukungan } \\
\end{array}$ \\
\hline & 3. Anggaran & $\begin{array}{ll}\text { - } & \text { Membantu kondisi anggaran } \\
\text { - } & \text { Mendidikan di sekolah } \\
\text { Mobilisasi dukungan terhadap } \\
\text { anggaran pendidikan di sekolah } \\
\text { - } \quad \text { Koordinasi dukungan terhadap } \\
\text { dukungan anggaran di sekolah } \\
\text { - } \quad \text { Evaluasi pelaksanaan dukungan } \\
\text { anggaran di sekolah }\end{array}$ \\
\hline \multirow[t]{3}{*}{ Sebagai Controling } & $\begin{array}{ll}\text { 1. } & \text { Kontrol terhadap } \\
& \text { perencanaan sekolah }\end{array}$ & $\begin{array}{ll}\text { - } & \text { Pengawasan terhadap proses } \\
\text { - } & \text { Pengambilan keputusan di sekolah } \\
& \text { di sekolah } \\
\text { - } & \text { Pengawasan terhadap proses } \\
\text { - } & \text { Perencanaan sekolah } \\
\text { Pengawasan terhadap kualitas } \\
\text { - } \\
\text { Perencanaan di sekolah } \\
\quad \text { pengawasan terhadap kualitas } \\
\end{array}$ \\
\hline & $\begin{array}{l}\text { 2. Kontrol terhadap } \\
\text { pelaksanaan program } \\
\text { sekolah }\end{array}$ & $\begin{array}{l}\text { - } \\
\text { - } \quad \text { Pengawasan terhadap organisasi } \\
\text { Pengawasan terhadap penjadwalan } \\
\text { program sekolah } \\
\text { - } \quad \text { Pengawasan terhadap alokasi } \\
\text { anggaran untuk pelaksanaan } \\
\text { program sekolah } \\
\text { - Pengawasan terhadap sumberdaya } \\
\text { pelaksanaan program sekolah } \\
\text { - Pengawasan terhadap partisipasi } \\
\text { sekolah terhadap program sekolah }\end{array}$ \\
\hline & $\begin{array}{l}\text { Kontrol terhadap output } \\
\text { pendidikan }\end{array}$ & $\begin{array}{ll}\text { - } & \text { Penilaian terhadap hasil ujian } \\
\text { nasional } \\
\text { - }\end{array}$ \\
\hline
\end{tabular}


Implementasi Kinerja Komite Sekolah...

\begin{tabular}{|c|c|c|}
\hline & & di sekolah \\
\hline \multirow[t]{3}{*}{ Mediator agency } & 1.Perencanaan & $\begin{array}{ll}\text { - } & \text { Menjadi penghubung antara KS } \\
\text { dengan masyarakat, KS dengan } \\
\text { Dewan Pendidikan, serta KS dengan } \\
\text { sekolah } \\
\text { - } \quad \text { Identifikasi aspirasi pendidikan } \\
\text { dalam masyarakat } \\
\text { - Membuat usulan kebijakan dan } \\
\text { program pendidikan kepada sekolah }\end{array}$ \\
\hline & 2. Pelaksanaan program & $\begin{array}{l}\text { - Sosialisasi kebijakan dan program } \\
\text { pendidikan sekolah terhadap } \\
\text { masyarakat } \\
\text { - Memfasilitasi berbagai masukan } \\
\text { terhadap kebijakan program } \\
\text { terhadap sekolah } \\
\text { - Menampung pengaduan dan } \\
\text { keluhan terhadap kebijakan dan } \\
\text { program pendidikan } \\
\text { Mengkomunikasikan pengaduan dan } \\
\text { keluhan masyarakat terhadap } \\
\text { instansi terkait dalam bidang } \\
\text { pendidikan di sekolah }\end{array}$ \\
\hline & 3. Sumber daya & $\begin{array}{ll}\text { - } & \text { Identifikasi kondisi sumber daya di } \\
\text { - } & \text { sekolah } \\
\text { - } & \text { Identifikasi sumber daya masyarakat } \\
\text { - } & \text { pendidikasi bantua masyarakat untuk } \\
\text { Koordinasi bantuan masyarakat }\end{array}$ \\
\hline
\end{tabular}

\section{Kinerja Organisasi}

Kata kinerja sering dipersandingkan dengan kata "performance" dalam bahasa Inggris yang berasal dari kata "perform" dan mempunyai makna melakukan atau menyelenggarakan ( $M$ \& Echols, 2008). Kinerja adalah perilaku yang ditujukan seseorang selama menjalankan pekerjaan, dalam pengertian kemampuan kerja atau prestasi kerja, kinerja merupakan tingkat keberhasilan didalam melaksanakan serta kemampuan untuk mencapai tujuan yang telah ditetapkan, dengan demikian, kinerja berarti kumpulan total prilaku kerja yang ditunjukkan seseorang, dan tingkat keberhasilannya dalam menjalankan tugas (Soeprijanto, 2010).

Griffin sebagaiman dikutip Al-alak dan Tarabieh, menyatakan bahwa "Organizational performance is described as the extent to which the organization is 
able to meet the needs of its stakeholders and its own needs for survival" (Alalak, 2011). Kinerja orgaisasi adalah gambaran dari sejauh mana organisasi tersebut mampu memenuhi kebutuhan stakeholder dan kebutuhannya sendiri untuk tetap survive.

Dari defenisi tersebut, dapat dimaknai bahwa kinerja organisasi merupakan aktifitas yang dilakukan oleh organisasi tersbut. Aktifitas yang dilakukan sebuah organisasi pada prinsipnya adalah untuk mempertahankan eksistensinya dan mengembangkan organisasi sesuai dengan tujuannya.

Faktor-Faktor Yang Mempengaruhi Kinerja Organisasi

Penerapan kinerja sebuah organisasi tidak terlepas dari faktor yang mempengaruhinya. Variabel kinerja organisasi tidak dapat berdiri sendiri, namun mempunyai hubungan dengan variabel lainnya. Secara umum faktor yang mempengaruhi aktivitas seseorang bersumber dari dalam diri (internal) dan faktor yang bersumber dari luar diri (eksternal).

Faktor internal merupakan faktor yang berhubungan dengan sifat-sifat seseorang, meliputi sikap, sifat-sifat kepribadian, sifat fisik, keinginan atau motivasi, umur, jenis kelamin, pendidikan, pengalaman kerja, latar belakang budaya dan variabelvariabel personal lainnya. Faktor eksternal merupakan faktor-faktor yang mempengaruhi kinerja karyawan yang berasal dari lingkungan, kepemimpinan, tindakan-tindakan rekan kerja, jenis latihan dan pengawasan, sistem upah dan lingkungan social (Siagian, 2012).

Selain faktor di atas, terdapat beberapa hal yang dapat mempengaruhi kinerja sebuah organisasi diantaranya, sumber daya manusia dalam organisasi (human resource), kompenisasi, dan motivasi (Pawero, 2016). Sumber daya manusia yang memadai akan mempengaruhi kinerja sebuah organisasi. Sumberdaya manusia cenderung memiliki kontribusi terhadap pengembangan sebuah organisasi.

Menurut Fitzenz sebagaimana dikutip Sudarmanto menggambarkan human capital dalam perpektif organisasi sebagai berikut (Sudarmanto, 2009): 
1. Ciri/ karateristik yang dibawa oleh seseorang dalam pekerjaannya yang mencakup kecerdasan, energi, sikap positif, dapat di andalkan, komitmen;

2. Kemampuan untuk belajar yang mencakup bakat, imajinasi, krativitas dan yang sering disebut kemampuan mencapai hasil melalui orang lain;

3. Motivasi untuk berbagi informasi dan pengetahuan yang tiada lain adalah semangat kelompok dan kecondongan pada sasaran.

Sudarmanto juga menjelaskan bahwa utnuk mencapai sasaran dan tujuan strategis organisasi, dibutuhkan individu atau sumber daya manusia yang kompeten, handal, dan visioner. Sedarmayanti menyebutkan bahwa peran sumber daya manusia dalam setiap proses kegiatan organisasi antara lain (Sedarmayanti, 2011):

1. Sebagai alat manajemen dalam rangka memberdayakan berbagai sumber untuk mencapai tujuan yang telah di tetapkan.

2. Sebagai pembaharu manajemen dalam rangka meningkatkan kinerja organisasi.

3. Sebagai insiator terhadap organisasi dalam rangka memanfaatkan peluang guna meningkatkan dan mengembangkan organisasi.

4. Sebagai mediator terhadap pihak lain dalam rangka meningkatkan kinerja organisasi.

5. Sebagai pemikir dalam rangka pengembangan organisasi.

Selain sumber daya manusia, kompensasi juga mempunyai pengaruh dalam kinerja organisasi. Kompensasi merupakan kontra prestasi terhadap penggunaan jasa atau tenaga yang telah diberikan oleh seseorang dalam melakukan pekerjaan. Sumber daya manusia yang memadai biasanya berhubungan erat dengan kompensasi yang diterima.

Kompensasi dalam sebuah kinerja dapat berupa upah kerja, gaji, tunjangan, dapat juga berupa penghargaan atau reward. Tujuan manajemen kompenisasi menurut Werter dan Davis sebagaimana dikutip Wibowo adalah sebagai berikut (Wibowo, 2012):

1. Memperoleh personel berkualitas

2. Mempertahankan karyawan/ angota yang ada

3. Memastikan keadilan 
4. Menghargai perilaku yang diiinginkan

5. Mengawasi biaya

6. Mematuhi peraturan

7. Memfasilitasi saling pengertian

8. Efisiensi administratif selanjutnya

\section{Metode}

Jenis penelitian ini adalah diskriptif kualitatif. Menurut Moleong, penelitian kualitatif adalah penelitian yang bermaksud untuk memahami fenomena tentang apa yang dialami oleh subjek penelitian misalnya perilaku, persepsi, motivasi, tindakan, dan lain-lain secara holistik dan dengan cara deskripsi dalam bentuk katakata dan bahasa, pada suatu konteks khusus yang alamiah dengan memanfaatkan berbagai metode alamiah (Moleong, 1995).

Subjek dalam penelitian ini adalah kepala MTs Alkhairaat Guraping Kecamatan Oba Utara dan MTs Durian Kecamatan Oba Utara Kota Tidore Kepulauan beserta ketua dan pengurus komite masing-masing madrasah. Teknik pengumpulan data Dalam penelitian ini peneliti menggunakan teknik observasi, wawancara kepada subjek penelitian.

\section{Hasil dan Pembahasan}

\section{Kinerja Komite MTs di Kecamatan Oba Utara}

Kinerja komite madrasah Tsanawiyah di kecamatan Oba Utara pada prinsipnya mengacu pada tugas dan fungsi yang tertuang pada peraturan yang telah ditetapkan pemerintah. Dalam Kepmendiknas No. 44/U/ 2002 tentang dewan pendidikan dan komite sekolah, menyebutkan bahwa komite sekolah berfungsi sebagai pemberi pertimbangan (advisory agency), pemberi dukungan (supporting agency), pengontrol (controlling agency), dan mediator.

Pelaksanaan sebuah kinerja organisasi termasuk komite madrasah, bagi peneliti harus dilacak mulai dari pembentukan dan rekrutmen personalia organisasi 
sebagai resource dalam menjalankan kinerja organisasi. Karena secara teoritis salah satu variabel yang mempengaruhi kinerja sebuah organisasi adalah sumber daya manusia.

Berdasarkan hasil analisis data penelitian, komite MTs di kecamatan Oba Utara dibentuk berdasarkan musyawarah orang tua murid dengan pihak sekolah. Musyawarah tersebut memanfaatkan momentum penerimaan buku laporan pendidikan peserta didik yang dihadiri langsung oleh orang tua /wali siswa.

Kriteria ketua dan pengurus komite yang ditetapkan masih sangat sederhana yaitu modal kepedulian. Artinya orang-orang yang dipercayakan oleh forum musyawarah tersebut telah memiliki modal dasar yakni motivasi untuk turut serta dalam membantu penyelenggaraan pendidikan madrasah.

Implementasi kinerja komite MTs di kecamatan Oba Utara umunya masih berada pada fungsi supporting agency, itu pun masih terbatas pada supporting dana serta sarana prasarana pendidikan.

Tabel 2. Kinerja Komite MTS Oba Utara sebagai Supporting Agency

\begin{tabular}{llll}
\hline \multicolumn{2}{c}{ MTS Durian } & \multicolumn{2}{c}{ MTS Alkhairaat Guraping } \\
\hline 1. & $\begin{array}{l}\text { Membantu pembiayayan konsumsi bagi } \\
\text { tenaga honorer }\end{array}$ & 1. & $\begin{array}{l}\text { Membantu pembiayayan konsumsi bagi } \\
\text { tenaga honorer }\end{array}$ \\
\hline 2. & Membuat jalan setapak sekolah & 2. $\begin{array}{l}\text { Membuat taman dan tempat santai di } \\
\text { halaman sekolah }\end{array}$ \\
\hline 3. & Membuat lapangan volly ball & 3. & Membuat lapangan badminton \\
\hline 4. & Membuat ruang parkiran & 4. & Membuat Kantin Sekolah \\
\hline 5. & Merehabilitasi sarana prasarana yang \\
rusak & & \\
\hline 6. & Membantu mensosialisasikan penerimaan \\
& siswa baru & \\
\hline 7. & Membantu kegiatan kesiswaan \\
\hline
\end{tabular}

Sumber : Hasil Analisis Data Penelitian

Peranan komite dalam menjalankan kinerjanya sebagai advisory agency yakni perencanaan sekolah, pelaksanaan program Kurikulum, proses belajar mengajar dan penilaian belum berjalan secara maksimal. Begitu juga dengan controling. 
Dalam melaksanakan kinerjanya sebagai mediator, komite madrasah menjalankan beberapa kegiatan diantaranya Menjadi penghubung antara sekolah dengan masyarakat, Membuat usulan kebijakan dan program pendidikan kepada sekolah, sosialisasi kebijakan dan program pendidikan sekolah terhadap masyarakat.

Peran komite madrasah selain membantu pihak sekolah dalam hal sarana prasarana, komite sekolah juga berperan dalam mensosialisasi setiap kebijakan yang berhubungan langsung dengan orang tua siswa atau masyarakat. Jika ada hal-hal yang bersifat penting bagi pengembangan sekolah yang membutuhkan dukungan orang tua siswa, biasanya komite selalu mengambil peran. Hal-hal seperti itu lebih efektif dilakuka oleh komite sekolah, karena komite sekolah merupakan wadah perwakilan orang tua peserta didik, tokoh masyarakat dan tokoh pendidik di sekolah tersebut.

Data tersebut di atas memberikan gambaran kinerja yang dilakukan oleh komite MTs di Kecamatan Oba Utara. Keterbatasan dan ketidak efektifan kinerja komite MTs Kecamatan Oba Utara tidak jauh beda dengan kinerja komite di Indonesia pada umumnya. Hasil penelitian dari Yayasan Satu Kasta Karya (YSKK) sepanjang tahun 2014-2015, tercatat tujuh temuan menarik kondisi kelembagaan dan kinerja Dewan Pendidikan dan Komite Sekolah di Indonesia:

1. Kinerja Dewan Pendidikan dan Komite Sekolah belum optimal

2. Sebagian besar pembentukan dewan pendidikan dan komite sekolah belum demokratis

3. Kemandirian dewan pendidikan dan komite sekolah masih setengah hati

4. Pemahaman yang lemah tentang kedudukan, peran dan fungsi dewan pendidikan dan komite sekolah

5. Komposisi keanggotaan dewan pendidikan dan komite sekolah diisi oleh orang yang tidak memiliki kepentingan langsung dan netral

6. Periode kepengurusan dewan pendidikan dan komite sekolah yang tidak jelas

7. Mekanisme kinerja dewan pendidikan dan komite sekolah yang tidak jelas. 
Gambaran tersebut di atas memberikan indikasi bahwa harapan akan partisipasi aktif masyarakat dalam pengelolaan pendidikan sebagaimana tertuang dalam konsep manajemen berbasis sekolah belum sepenuhnya terlaksana dengan baik.

\section{Kendala yang Dihadapi Komite MTs Dalam Melaksanakan Kinerjanya}

Pelaksanaan sebuah kinerja organisasi tidak terlepas dari kendala yang di hadapi. Dalam pelaksanaan kinerja komite MTs di Oba Utara, terdapat beberapa hal yang menjadi kendala diantaranya:

1. Minimnya Sumber daya manusia

Sebagaimana telah dijelaskan sebelumnya bahwa sumberdaya organisasi memainkan peranan penting dalam menjalankan roda organisasi. Hasil anaisis data penelitian menggambarkan bahwa keterbatasan sumber daya manusia merupakan salah satu kendala kinerja komite MTs di Kecamatan Oba Utara. Kepedulian saja tidak cukup untuk menjalankan roda organisasi komite, tetapi membutuhkan orang yang memilki pemahaman terhadap fungsi komite sehingga kinerja komite tersebut dapat berjalan sesuai dengan tujuan yang sesungguhnya.

Pengurus yang dipercayakan untuk mejadi komite sekolah ini pada umumnya belum memahami sesungguhnya peran dan fungsi komite sebagaimana tertuang dalam peraturan yang ditetapkan. Kepedulian pemerintah terhadap komite sekolah juga merupakan faktor yang menyebabkan minimnya sumber daya manusia pada pengurus komite sekolah.

Sejatinya sebuah organisasi yang sehat dan berorientasi pada pencapaian visi organisasi adalah mempersiapkan sumber daya manusianya. Idealnya setelah terbentuknya pengurus komite sekolah, mereka harus diberikan bimbingan khusus oleh pemerintah atau lembaga terkait, sehingga mereka (pengurus) komite sekolah faham akan apa yang mestinya dilakukan. 
2. Keterbatasan Waktu dan Kesempatan

Kendala lain yang dihadapi pengurus komite MTs Kecamatan Oba Utara adalah keterbatasan waktu dan kesempatan untuk melaksanakan kinerja organisasi. Kendala waktu dan kesempatan dimaksud adalah tidak sepenuhnya pengurus komite MTs selalu aktif dalam setiap kegiatan atau pelaksanaan kinerja komite.

Organisasi komite madrasah merupakan organisasi non profit/ nir laba yang dijalankan oleh kepengurusan untuk membantu penyelenggaraan pendidikan di sekolah. Sebagai organisasi nir laba yang beranggotakan orang tua siswa dan tokoh masyarakat, tentu mereka memiliki profesei dan pekerjaan yang berbeda.

Kesibukan dengan pekerjaan dan tugas pokok yang dimilki oleh pengurus komite MTs membuat kesempatan kami untuk menjalankan kegiatan dan program komite madrasah terabaikan. Menjalankan kinerja organisasi yang hanya bermodal kepedulian dan pengabdian menjadikan organisasi ini tidak bisa memaksa setiap anggota dengan pengurus lainnya untuk selalu aktif menjalankan kinerja keorganisasian. Berbeda dengan organisasi lain yang jelas mempuyai kompenisasi yang jelas, tentu dapat memaksa dan mengikat pengurus dan anggotanya untuk bekerja.

Memang secara teoritis kinerja juga sangat tergantung pada kompenisasi dari sebuah pekerjaan. Meskipun para pengurus komite MTs bekerja tanpa mengharapkan kompenisasi secara materi, namun kompenisasi merupakan bagian dari stimulus untuk membangitkan motivasi seseorang dalam melakukan suatu kegiatan.

\section{Simpulan}

Berdasarkan hasil penelitian di atas, dapat ditarik kesimpulan sebagai berikut.

1. Kinerja komite madrasah Tsanawiyah di Kecamatan Oba Utara belum berjalan secara maksimal. Implementasi kinerja komite MTs di kecamatan 
Oba Utara umunya masih berada pada fungsi supporting agency, itu pun masih terbatas pada supporting dana serta sarana prasarana pendidikan.

2. Kendala yang di hadapi oleh komite madrasah Tsanawiyah di kecamatan Oba Utara adalah minimnya sumberdaya manusia. Pengurus yang dipercayakan untuk menjadi komite sekolah ini pada umumnya belum memahami sesungguhnya peran dan fungsi komite sebagaimana tertuang dalam peraturan yang ditetapkan. Kepedulian pemerintah terhadap komite sekolah juga merupakan faktor yang menyebabkan minimnya sumber daya manusia pada pengurus komite sekolah. Faktor kedua yang menjadi kendala adalah ketersediaan waktu dan kesempatan pengurus komite dalam menjalankan tugas dan fungsi komite madrasah.

\section{Referensi}

Al-alak, B. A. S. T. (2011). Gaining Competitive Advantage And Organizational Performance Through Customer Orientation, Innovation Differentiation And Market Differentiation. International Journal of Economics and Management Sciences, 1(5).

Barrera, F., \& et.all. (2009). Decentralized Decision-Making in Schools The Theory and Evidence on School-Based Management. The International Bank for Reconstruction and Development.

Basic Education Capacity Trust Fund (BEC-TF). (2011). Meningkatkan Manajemen Berbasis Sekolah di Indonesia. Sektor Pembangunan Manusia Bank Dunia.

Daeng Pawero, A. M. V. (2018). Analisis Kritis Kebijakan Kurikulum Antara KBK, KTSP, dan K-13. Jurnal Ilmiah Iqra', 12(1), 42. https://doi.org/10.30984/jii.v12i1.889

Hasbullah. (2010). Otonomi Pendidikan Kebijakan Otonomi Daerah dan Implikasinya Terhadap Penyelenggaraan Pendidikan. Rajawali Press.

M, J., \& Echols, H. S. (2008). Kamus Inggris Indonesia. Gramedia Pustaka Utama.

Moleong, L. J. (1995). Metodologi Penelitian Kualitatif. Rosdakarya.

Pawero, A. M. V. D. (2016). Strategi Internasionalisasi Perguruan Tinggi Swasta. UIN Maulana Malik Ibrahim Malang. 
Pawero, A. M. V. D. (2017). Analisis Kritis Kebijakan Standar Kompetensi Lulusan (SKL) Dan Standar Isi Kurikulum Pendidikan Agama Islam. Journal of Islamic Education Policy, 2(2), 166.

Sedarmayanti. (2011). Manajemen Sumberdaya Manusia Reformasi Birokrasi dan Manajemen Pegawai Negeri Sipil. Refika Aditama.

Siagian, S. P. (2012). Fungsi-Fungsi Manajerial. Bumi Aksara.

Soeprijanto. (2010). Pengukuran Kinerja Guru Praktik Kejuruan. CV. Tursina.

Sudarmanto. (2009). Kinerja dan Pengembangan Kompetensi SDM. Pustaka Pelajar.

Tilaar, H. A. R. (2009). Kekuasaan dan Pendidikan; Manajemen pendidikan Nasional Dalam Pusaran Kekuasaan. Rineka Cipta.

Tim Redaksi Sinar Grafika. (2007). Undang-Undang Sistem Pendidikan Nasional Nomor 20 Tahun 2003. Sinar Grafika.

Umiraso, \& Gojali, I. (2011). Manajemen Mutu Sekolah di Era Otonomi Pendidikan; Menjual Mutu Pendidikan Dengan Pendekatan Quality Control bagi Pelaku Lembaga Pendidikan. Ircisod.

Wibowo. (2012). Manajemen Kinerja. Raja Grafindo Persada.

World Bank. (2013). Pelaksanaan Manajemen Berbasis Sekolah di Indonesia. World Bank. 